\title{
BIOCHEMICAL CHARACTERIZATION OF TWO SIBLING SPECIES IN THE LIVERWORT PELLIA EPIPHYLLA (L.) CORDA (HEPATICAE, PELLIACEAE)
}

\author{
WIESŁAW PRUS-GŁOWACKI ${ }^{1}$, ROMAN ZIELIŃSKI ${ }^{2}$ AND JERZY SZWEYKOWSKI ${ }^{1}$ \\ ${ }^{1}$ Department of Genetics, Institute of Experimental Biology, \\ Adam Mickiewicz University, Miẹdzychodzka 5, 60-371 Poznań, Poland \\ ${ }^{2}$ Department of Genetics, Faculty of Natural Sciences, \\ Szczecin University, Łukasińskiego 43, 71-215 Szczecin, Poland
}

(Received: May 9, 1997. Accepted: March 11, 1998)

\begin{abstract}
Two sibling species in the Pellia epiphylla (L.) Corda ( $\mathrm{n}=9$ ) complex, viz. Pellia epiphylla sp. $N$ and Pellia epiphylla sp. $S$ were compared in their protein concentration and in the dynamics and also in relative activity of some enzymes: malate dehydrogenase $(\mathrm{MDH})$, esterase (EST), peroxidase (PX) and aspartate aminotransferase (GOT). Serological properties of their antigens were studied as well. Activity of malate dehydrogenase, esterase and aspartate aminotransferase was significantly higher in clons of Pellia epiphylla $\mathrm{N}$ than Pellia epiphylla $\mathrm{S}$.

Some differences in soluble protein concentration and in the quantities of the AI to AIV antigens between the two sibling species were detected.
\end{abstract}

KEY WORDS: Hepaticae, Pellia epiphylla $(\mathrm{n}=9)$ complex, sibling species, biochemical variation.

\section{INTRODUCTION}

Electrophoretic research on various populations of Pellia epiphylla $(\mathrm{n}=9)$ collected in Poland resulted in the rather unexpected discovery of the complex nature of this species. First, Szweykowski et al. (1981) stated that there are at least three different peroxidase phenotypes in Polish populations of this species; they were called PX1a, PX2a and PX3. Further studies by Zieliński (1984, 1987a, 1987b) revealed, that the differences between the phenotypes PX1a and PX2a, as contrasted with the phenotype PX3, are of such a magnitude (different alleles fixed in 9 out of 20 loci studied) that PX1a and PX2a should be treated as representing two distinct species. The species were called, for the time being, Pellia epiphylla sp. $S$, with two different peroxidase phenotypes (i.e. PXla and PX2a), and Pellia epiphylla sp. $N$, having only one, at least in Poland, peroxidase phenotype (PX3). As all attempts to find morphological or anatomical differences between PX1a and PX2a individuals have failed so far, they fall into the category of sibling species. This was one of the very first reports on the existence of sibling species in Bryophytes.

The two species differ in their geographical distributions (Szweykowski et al. 1995); also some karyological differences were observed (Zieliński 1987a, Chudzińska, unpublished data). The aim of the present paper was a comparison of the two species in some biochemical aspects: protein concentration in extracts of the thalli, activity of selected enzymes and some serological characters were studied.

\section{MATERIAL AND METHODS}

Nine samples of Pellia epiphylla sp. $S$ and 5 samples of Pellia epiphylla sp. $N$, collected in various places in Poland, were studied (Table 1). Individual thalli were planted into plastic pots filled with peat. After several months of cultiva-

TABLE 1. List of the samples of Pellia epiphylla used in the study

\begin{tabular}{|c|c|}
\hline Clone no. & Place of collection \\
\hline \multicolumn{2}{|c|}{ Pellia epiphylla sp. $S$} \\
\hline 94 & Boczań, Tatra Mts \\
\hline 178 & Boczań, Tatra Mts \\
\hline 272 & Boczań, Tatra Mts \\
\hline 175 & Zbocze Wysokiego, Tatra Mts \\
\hline 180 & Zbocze Wysokiego, Tatra Mts \\
\hline 273 & Zbocze Wysokiego, Tatra Mts \\
\hline 87 & Wisla Czarne, Barania Góra Mts \\
\hline 146 & Beretki, Bieszczady Mts \\
\hline 214 & Wejherowo \\
\hline \multicolumn{2}{|c|}{ Pellia epiphylla sp. $N$} \\
\hline 205 & Pestkownica near Kuźnica Żelichowska \\
\hline 192 & Kampinos near Warszawa \\
\hline 203 & Miłomłyn near Ostróda \\
\hline 165 & Warnowo, Wolin Isl \\
\hline 235 & Klembów near Tłuszcz \\
\hline
\end{tabular}


tion these thalli formed colonies of the genetically identical plants. The electrophoretic phenotypes of peroxidase (PXla, PX2a and PX3) were identified in each clone according to the method described by Zielinski (1984, 1987a). Moreover, chromosome numbers were checked in all the clones. The number of chromosomes $n=9$ was detected in the all samples as described earlier (Zielinski 1987a).

One gram of fresh thalli was taken from each clone and cleaned from remains of peat and other debris. For protein extraction the thalli were ground in a cooled to $-16^{\circ} \mathrm{C}$ mortar, in the $0.1 \mathrm{M}$. extraction buffer (Tris- $\mathrm{H}_{3} \mathrm{BO}_{3}$-EDTA), $\mathrm{pH} 7.4$. (1 part of thalli: 4 parts of extraction buffer). The homogenate was centrifuged at $4^{\circ} \mathrm{C}$ and the supernatants were used for further analyses.

The extracts were analysed for protein content by the Lowry method. Variation in the activity of some enzymes was studied. Each kind of analyses were done in triplicate for single clone and mean value for the data were calculated. Serological analyses (immunodiffusion, simple immuno-electrophoresis, tandem - and rocket immunoelectrophoresis) were carried out as well.

\section{Enzymatic activity analyses}

The analysis of activity of the enzymes was performed according to the methods of Worthington (1972) with some described below minor modifications The enzymes activity were measured every 10 or 20 minutes, on the basis of colorimetric reactions at $40^{\circ} \mathrm{C}$.

The analysis of selected enzymes aimed to reveal if the two sibling species from Pellia epiphylla complex differ in these properties.

As a measure of enzymes activity the increase of the absorbance in time was applied. For particular enzyme the research of dependence of effect of enzymatic reaction upon the time was performed. The results were presented as histograms drawn for the value where the curve of absorbance reached the maximum, but was still proportional and linear to factor of time of reaction.

1. Malate dehydrogenase (MDH-E.C.1.1.1.37). Five $\mathrm{ml}$ of staining mixture were put into each of the 28 test-tubes used. The staining mixture contained glycine buffer $(1.5 \mathrm{~g}$ of glycine, $196 \mathrm{ml}$ of $\mathrm{H}_{2} \mathrm{O}$ adjusted with $\mathrm{NaOH}$ to $\mathrm{pH}$ $8.7), 140 \mathrm{mg}$ of L-malic acid, $10 \mathrm{mg}$ of nitro blue tetrazolium and $10 \mathrm{mg}$ of $\mathrm{NADH}_{2}$. The test tubes were placed in ice and $50 \mu \mathrm{l}$ of thalli extract was added to each of them except the tube for blank test.. The results were read out at $625 \mathrm{~nm}$.

2. Esterase (EST-E.C.3.1.1.6). Esterase activity was estimated for the wave length $540 \mathrm{~nm}$. The staining mixture consisted of $150 \mathrm{ml}$ phosphate buffer $0.1 \mathrm{M}(\mathrm{pH} 6.0), 150 \mathrm{mg}$ of alpha-naphtyl acetate, $75 \mathrm{mg}$ of Fast Blue RR salt dissolved in $2 \mathrm{ml}$ of di-methylformamide.

3. Peroxidase (PX-E.C.1.11.1.7). Enzymatic activity was measured, for the wave length $450 \mathrm{~nm}$. The staining mixture consisted of $75 \mathrm{mg}$ of 3-amino-9-ethyl-carbasole, $3 \mathrm{ml}$ of di-methylformamide, $3 \mathrm{ml}$ of $0.1 \% \mathrm{MgCl}_{2}$ and $8 \mathrm{ml}$ of $3 \%$ $\mathrm{H}_{2} \mathrm{O}_{2}$, all dissolved in acetate buffer $0.1 \mathrm{M}(\mathrm{pH}$ 5.0). Because of the extremely high activity of this enzyme the amount of extract used for the analyses was reduced to $20 \mu \mathrm{l}$.

4. Aspartate aminotransferase (GOT-E.C.2.6.11). Analysis of the enzyme activity was performed for the wave length $550 \mathrm{~nm}$. The staining mixture consisted of $340 \mathrm{mg}$ aspartic acid, $150 \mathrm{mg}$ alpha-ketoglutaric acid, $150 \mathrm{mg}$ Fast Blue BB salt, $4 \mathrm{mg}$ of pyridoxal-5-phosphate.
The absorbance values from enzyme activity estimations were recalculated per $\mathrm{mg}$ of total soluble proteins.

\section{Serological analyses}

Serological analyses were carried out as described in the previous papers (Szweykowski et al. 1981, Prus-Głowacki and Nowak 1982, Prus-Głowacki and Nowak-Bzowy 1986).

Antiserum against proteins of Pellia borealis (a tetraploid species of $n=18$ ), with the titer of $1: 128$, was additionally concentrated to the half of its previous volume with aquacid. Comparison of the relative amount of particular antigens was performed by rocket immunoelectrophoresis and estimation of the rocket height, which correlated with the quantity of a given antigen in the sample studied.

\section{RESULTS}

\section{Total soluble protein content}

The average contents of protein in extracts of Pellia epiphylla sp. $S$ and Pellia epiphylla sp. $N$, were, respectively, $17.69 \mathrm{mg} / \mathrm{ml}$ and $14.74 \mathrm{mg} / \mathrm{ml}$ (Table 2).

TABLE 2. Concentration of proteins in the clones of Pellia epiphylla sp. $S$ and Pellia epiphylla sp. $N$, in $\mathrm{mg}$ per $\mathrm{ml}$ of extract and in $\mathrm{mg}$ per gram of fresh weight

\begin{tabular}{|c|c|c|c|c|}
\hline Clone no. & $\mathrm{mg} / \mathrm{ml}$ & SD & $\mathrm{R}$ & $\mathrm{mg} / \mathrm{g}$ f.w. \\
\hline \multicolumn{5}{|c|}{ Pellia epiphylla sp. $S$} \\
\hline $\begin{array}{c}94 \\
272 \\
273 \\
214 \\
178 \\
175 \\
180 \\
146 \\
87\end{array}$ & $\begin{array}{l}15.20 \\
15.85 \\
18.00 \\
15.30 \\
21.00 \\
15.50 \\
18.10 \\
21.30 \\
19.00\end{array}$ & & & $\begin{array}{l}60.80 \\
63.40 \\
72.00 \\
61.20 \\
84.00 \\
62.00 \\
72.40 \\
85.20 \\
76.00\end{array}$ \\
\hline & $x: 17.69$ & 2.51 & 4.30 & $x: 70.10$ \\
\hline \multicolumn{5}{|c|}{ Pellia epiphylla sp. $N$} \\
\hline $\begin{array}{l}192 \\
205 \\
203 \\
165 \\
235\end{array}$ & $\begin{array}{l}16.10 \\
15.90 \\
18.10 \\
12.80 \\
10.80\end{array}$ & & & $\begin{array}{l}64.40 \\
63.60 \\
72.40 \\
51.20 \\
43.20\end{array}$ \\
\hline 235 & $x: 14.74$ & 6.75 & 7.30 & $\mathrm{x}: 59.00$ \\
\hline
\end{tabular}

Notwithstanding the extensive variation in protein concentrations between samples (standard deviations for Pellia epiphylla sp. $S$ and Pellia epiphylla sp. $N$ were 2.51 ), however these differences were not statistically significant. The protein concentration, calculated in $\mathrm{mg} / \mathrm{g}$ of fresh thalli, was also higher for the former species $(S-70.1 \mathrm{mg} / \mathrm{g})$ in comparison with the latter one $(N-59.0 \mathrm{mg} / \mathrm{g})$. Considerable differences in this parameter were detected between individual samples.

\section{Enzymes activity}

The results of enzyme activity are presented in Fig. 1. The $\mathrm{MDH}$ activity measured after and 50 minutes, was about 4 ti- 


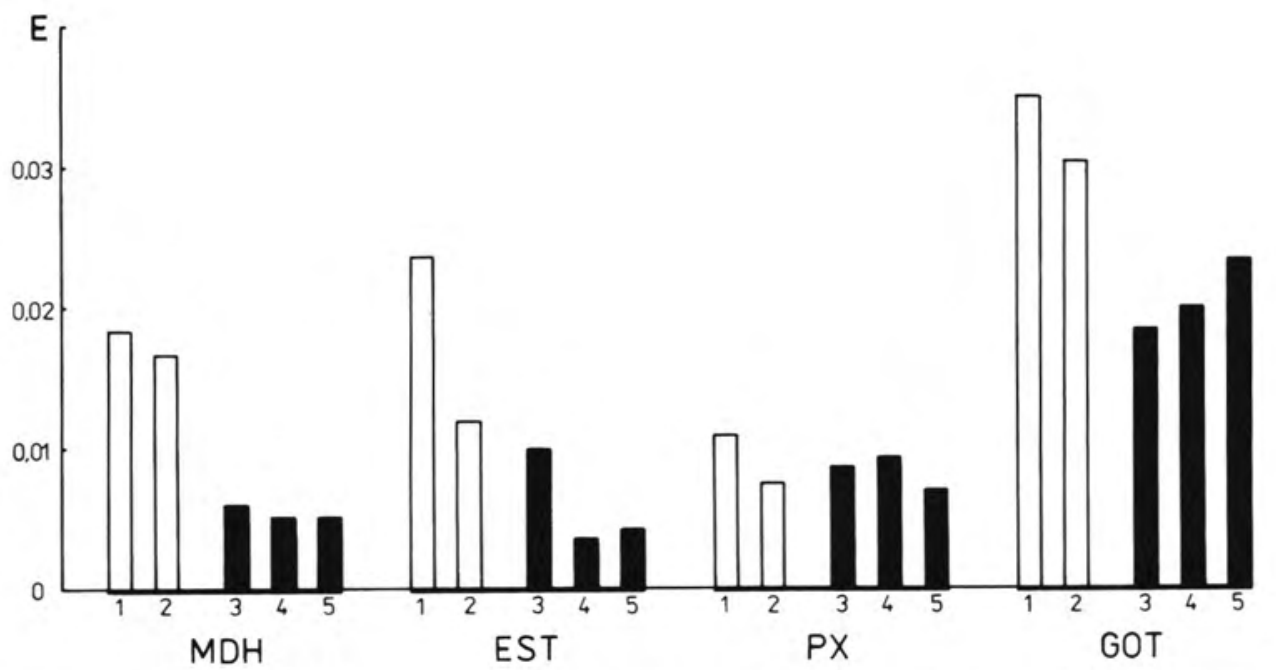

Fig. 1. Comparison of the activity of malate dehydrogenase (MDH), esterase (EST), peroxidase (PX) and aspartate transferase (GOT) in various clons of Pellia epiphylla N (open bars) and Pellia epiphylla S (black bars). Clons numbers: 1-205, 2-192, 3-175, 4-94 and 5-273. E - value of absorbance.

mes lower in extracts of Pellia epiphylla sp. $S$ than in extracts of species. Pellia epiphylla $N$ (Fig. 1). The mean absorbance values were 0.0051 and $0 ., 0195$ respectively.

An almost threefold lower esterase activity was observed after $15 \mathrm{~min}$. in Pellia epiphylla sp. S, as compared with Pellia epiphylla sp. $N$. The mean absorbance values were 0.0060 in extract from clons Pellia epiphylla S and 0.0180 in P. epiphylla $\mathrm{N}$.

The peroxidase activity does not differ significantly among the studied clons of Pellia sp. However clon no. 205 (P. epiphylla $\mathrm{N}$ ) posses the highest activity of peroxidase among the studied samples.

Aspartate aminotransferase exhibited also similar differences in activity between the two species: after $10 \mathrm{~min}$. The mean absorbance values amounted to 0.018 in Pellia epipylla sp. $S$ and 0.023 in the other species - Pellia epiphylla $\mathrm{N}$.

TABLE 3. Relative amounts of common antigens AI to AIV in the studied clones of Pellia epiphylla sp. $S$ and Pellia epiphylla sp. $N$, presented as hights of immunoelectrophoretic rockets (in $\mathrm{mm}$ )

\begin{tabular}{c|c|c|c|c}
\hline Clone no. & AI & AII & AIII & AIV \\
\hline \multicolumn{5}{c}{ Pellia epiphylla sp. S } \\
\hline 175 & 18.8 & 11.6 & 3.5 & 1.1 \\
87 & 16.3 & 3.2 & 5.8 & 0.8 \\
94 & 2.4 & 8.3 & 5.8 & 0.1 \\
273 & 13.6 & 20.4 & 5.6 & 0.2 \\
272 & - & 15.8 & 5.0 & 0.1 \\
146 & 21.5 & 10.0 & 4.4 & 0.5 \\
214 & - & 11.9 & 4.5 & 0.1 \\
178 & - & 2.9 & 3.1 & 1.2 \\
180 & - & 5.0 & 3.7 & 1.1 \\
\hline Average & 14.5 & 9.9 & 4.6 & 0.6 \\
\hline \multicolumn{5}{|c|}{ Pellia epiphylla sp. N } \\
\hline 192 & 8.3 & 1.4 & 5.8 & 0.3 \\
205 & 9.3 & 5.0 & 5.7 & 0.3 \\
203 & 11.2 & 8.9 & 4.0 & 0.6 \\
165 & 8.9 & 1.4 & 3.8 & 0.1 \\
\hline Average & 9.4 & 4.2 & 4.8 & 0.3 \\
\hline
\end{tabular}

The three enzymes (MDH, GOT and EST) manifested the differences between the two species: At the similar average protein concentration in the extracts $(16.2$ and $16.0 \mathrm{mg} / \mathrm{ml}$, respectively), the average activity of the studied enzymes was lower for Pellia epiphylla sp. S than for the Pellia epiphylla sp. N).

\section{Serological analyses}

Presence of common four antigens, denoted AI to AIV, was detected. Amounts of the antigens I and II were higher in Pellia epiphylla sp. $S$ than in the $\mathrm{N}$ species (Table 3). Because of the considerable inter-clone variation in the amounts of individual antigens, no significant differences could be disclosed between the sibling species. Nevertheless, serological properties of proteins in Pellia epiphylla sp. $S$ clones allowed to distinguish two types of patterns typical for the species. In one of the patterns, exemplified by clones no. 175, 87, 273, 146, high amounts of antigen I were present while in the other (clones no. $94,272,214,178$ and 180) the antigen was absent or present in very low amounts. A significant inter-clone variation was noted also in the amounts of antigen II (Table 3, Fig. 2).

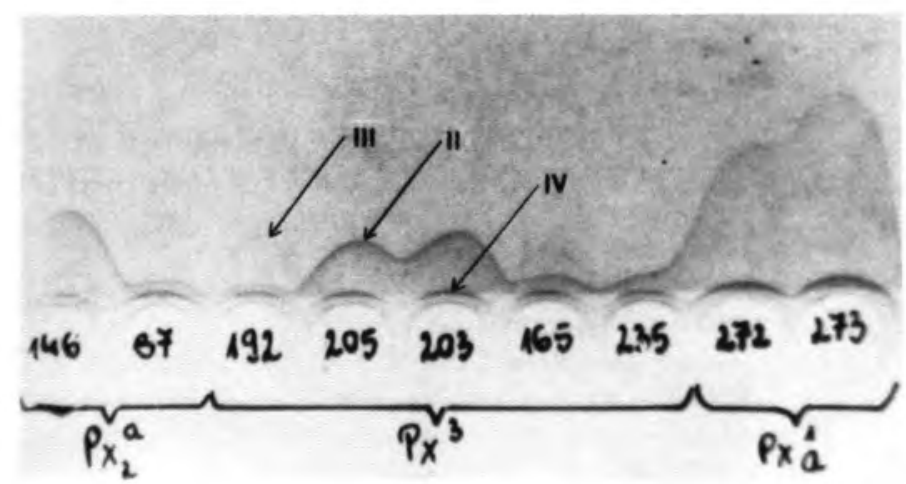

Fig. 2. Rocket immunoelectrophoresis of electrophoretic phenotypes (PX1, PX2, PX3) of Pellia epiphylla complex proteins. Antiserum against proteins of Pellia borealis - natural poliploid of Pellia epiphylla. Numbers denote individual clone. Roman numbers - I to IV denote individual antigens. 
The general serological patterns differed between $P$. epiphylla sp. $S$ and $P$. epiphylla sp. $N$ clones. In addition, some serological differences were also detected between clones of P. epipylla sp. $N$ (Fig. 2).

\section{DISCUSSION}

Sibling species were discovered in liverworts by identifying their electrophoretic phenotypes in the following Bryophyte species: Pellia epiphylla (L.) Corda (Szweykowski et al. 1981, Zieliński 1984, 1987a, 1987b), Pellia endiviifolia (Dicks.) Dum. (Zieliński 1987a), Conocephalum conicum (L.), (Szweykowski, Krzakowa 1979, Krzakowa, Szweykowski 1977, Szweykowski et al. 1981, Odrzykoski 1985, 1986, 1987, Odrzykoski, Szweykowski 1991), Riccia dictyospora Howe (Dewey 1989) and Aneura pinguis (L.) Dum. (Szweykowski, Odrzykoski 1990). In all the mentioned cases, sibling species have been different in their multilocus electrophoretic phenotypes to such an extent that the values of their diversity, measured by Neis genetic distance (Nei 1972), is equal to or even exceeded those observed between generally accepted standards for the so called good species in various groups of organisms, particularly in flowering plants (Odrzykoski and Szweykowski 1991).

The results presented in this paper shows that the sibling species in Pellia epiphylla complex differ profoundly in the activity of the studied enzymes and serological properties of proteins. Thus, the differences between them must have also the physiological and ecological basis. Moreover, as it has been shown by Szweykowski et al. (1995) the studied sibling species exhibit also allopatric geographical distributions in Poland. The search for morphological differences in Pellia (Zieliński 1987a) have given, however, equivocal results. In contrast, in case of other sibling species in Bryophytes, such studies have been successful (Buczkowska, Szweykowski in preparation). Taking all these circumstances into account we can conclude that the existence of sibling species in liverworts is a well grounded phenomenon; the classical taxonomy should take this fact into consideration.

\section{LITERATURE CITED}

DEWEY R.M., 1989. Electrophoretic studies in Riccia subgenus Riccia. Bryologist 99: 344-353.

KRZAKOWA M., SZWEYKOWSKI J., 1977. Peroxidases as taxonomic characters in two critical Pellia taxa (Hepaticae, Pelliaceae). Bull. Pol. Acad. Sci. (Biol.) 25(3): 203-204.
NEI M., 1972. Genetic distances between populations. Amer. Natur. 106: 283-292.

ODRZYKOSKI I.J., 1985. Conocephalum conicum as a group of sibling species. Abstracta Botanica 9: 28.

ODRZYKOSKI I.J., 1986. Genetic structure of natural populations of Conocephalum conicum. Ph.D. Thesis, Adam Mickiewicz University, Poznań, Poland.

ODRZYKOSKI I.J., 1987. Genetic evidence for reproductive isolation between European forms of Conocephalum conicum. Symposia Biol. Hung. 35: 577-587.

ODRZYKOSKI I.J., CHUDZIŃSKA E., SZWEYKOWSKI J., 1996. The hybrid origin of the polyploid liverwort Pellia borealis. Genetica 98: 75-86.

ODRZYKOSKI I.J., SZWEYKOWSKI J., 1991. Genetic differentiation without concordant morphological divergence in the thallose liverwort Conocephalum conicum. Pl. Syst. Evol. 178: 135-151.

PRUS-GŁOWACKI W., NOWAK R., 1982. Serological comparison of two liverworts Pellia epiphylla $\mathrm{n}=9$ and Pellia borealis $\mathrm{n}=18 . \mathrm{Ge}-$ netica Polonica 23, 4: 183-188.

PRUS-GŁOWACKI W., NOWAK-BZOWY R., 1986. Serological variability of the Pellia endiviifolia - Pellia megaspora complex. Acta Soc. Bot. Pol. 55(4): 565-575.

SZWEYKOWSKI J., KRZAKOWA M., 1977. Peroxidases as taxonomic characters in two critical Pellia taxa (Hepaticae, Pelliaceae). Bull. Pol. Acad. Sci. (Biol.) 25(3): 203-204.

SZWEYKOWSKI J., ODRZYKOSKI I.J., 1990. Chemical differentiation of Aneura pinguis (L.) Dum. (Hepaticae, Aneuraceae) in Poland an some comments on application of enzymatic markers in bryology. In: ZINSMEISTER H.D., MUES R. (eds.): Bryophytes Their Chemistry and Chemical Taxonomy, Clarendon Press, Oxford: 437-448.

SZWEYKOWSKI J., ZIELIŃSKI R., MENDELAK M., 1981. Variation of peroxidase izoenzymes in central European taxa of the liverwort genus Pellia. Bull. Pol. Acad. Sci. (Biol.) 28(12): 9-19.

SZWEYKOWSKI J., ZIELIŃSKI R., ODRZYKOSKI I., CHUDZIŃSKA E., 1995. Geographic distribution of Pellia spp. (Hepaticae, Metzgeriales) in Poland based on electrophoretic identification. Acta Soc. Bot. Pol. 64(1): 59-70.

WORTHINGTON, 1972. Enzyme Manual. Worthington Biochemical Corporation, New Jersey, USA.

ZIELIŃSKI R., 1984. Electrophoretic and cytological study of the Pellia epiphylla and P. borealis complex. J. Hattori Bot. Lab. 56: 263269.

ZIELIŃSKI R., 1987a. Genetic variation of the liverwort genus Pellia with special reference to central European teritory. Univ. of Szczecin Press, Szczecin.

ZIELIŃSKI R., 1987b. Genetic variation of the liverwort genus Pellia with special reference to central European teritory. Symposia Bot. Hung. 35: 175-189.

\section{BIOCHEMICZNA CHARAKTERYSTYKA DWÓCH GATUNKÓW BLIZNIACZYCH U WĄTROBOWCA PELLIA EPIPHYLLA (L.) CORDA (HEPATICAE, PELLIACEAE)}

\section{STRESZCZENIE}

Dwa gatunki bliźniacze w kompleksie Pellia epiphylla (L.) Corda $\mathrm{n}=9$, to jest $P$. epiphylla sp. $N$ i Pellia epipylla sp. $S$ porównano pod względem zawartości białka w plechach i aktywności czterech enzymów (dehydrogenazy jabłczanowej MDH, esterazy EST, peroksydazy PX, aminotransferazy asparaginianowej GOT). Badano także właściwości antygenowe białek u obu taksonów.Aktywność badanych enzymów była znacząco wyższa u $P$. epiphylla $\mathrm{N}$. Wykryto również różnice w zawartości bialek rozpuszczalnych jak również w ilości homologicznych antygenów u badanych gatunków bliźniaczych.

SŁOWA KLUCZOWE: wạtrobowce, kompleks Pellia epiphylla n=9, gatunki bliźniacze, zmienność biochemiczna. 